\title{
CAREER COUNSELLING: A CONSTRUCTIVE INTERACTION BETWEEN SCIENCE AND PRACTICE
}

\author{
Liudmyla Bazyl', Valerii Orlov² \\ 1 Doctor of Sciences in Education, Associate Professor, Scientific Secretary of the Institute of vocational education and training \\ of NAES of Ukraine \\ http://orcid.org/0000-0003-4130-5436 \\ ResearcherID: P-4545-2017, e-mail:ljudmilabazyl@gmail.com \\ 2 Doctor of Sciences in Education, Professor, Senior Research Associate Institute of vocational education and training of NAES \\ of Ukraine \\ http://orcid.org/0000-0002-1843-390X \\ ResearcherID: W-3247-2018, e-mail:v.f.orlov@ukr.net
}

\begin{abstract}
The article analyzes the current status of student counselling in vocational education institutions, contextualizes findings on this problem and discloses contradictory points of counselling. It is justified that vocational education institutions normally view professional career counselling as the processes of dealing with and solving students' internal conflicts within professional self-determination. Career centres are positioned to be the implementers of the ideas of student career counselling. However, such research methods as theoretical analysis, comparison, pedagogical observations and logical generalization made it possible to specify some typical problematic aspects of career counselling within professional development of the modern personality, which are mostly reduced to the inconsistencies of the ideal and real images of the chosen career, subjective perception and ignoring of value orientations in relation to professional success and career growth in a market environment, irrelevant self-assessment of individual and personal qualities, etc. The authors of the research suggest some promising ways of solving the problematic aspects of student counselling in vocational education institutions, which are conceptualized in the mechanisms of a productive innovative interaction between scholars from the Institute for Vocational Education of the National Academy of Pedagogical Sciences (NAPS) of Ukraine and the teaching staff and are implemented in the framework of introducing the system of professional career counselling in vocational education.
\end{abstract}

Keywords: professional career, centres for professional career, student counselling, professional career counselling, vocational education.

Introduction. Socioeconomic changes caused by civilizational transformations such as dynamic progress of production and the emergence of a market economy in Ukraine require that specialists should review and reconsider value orientations, the importance of acquired competencies and the designing of career development strategies. The system of vocational education gradually adopts a new educational paradigm extrapolated from the economically developed countries, where a form of ownership and a source of profit are "determined intelligence, that is, the ability to continuously gain and effectively apply the acquired knowledge, skills, experience and to build trajectories of career development and to discover optimal ways of self-realization in an unstable society" (Falkenberg, 1997). In this regard, it is essential to study how to implement the following paradigmatic ideas in vocational education institutions: to analytically comprehend the realities of student career counselling; to identify its positive achievements and problematic aspects; to outline certain effective methods and means of their solving.

Materials and methods. Over the past 20 years, different aspects of career counselling have been studied by many scholars. For one, the main motives, goals and mechanisms of motivation towards professional career were justified by E. Berne, R. Burns, V. Lozovetska, E. Sandstrom, L. Vygotsky, 
D. Winter et al. The peculiarities of personality development within the framework of planning and realizing professional career were highlighted by V. Berg, E. Klimov, O. Kucheriavyi, L. Peter, B. Schwalbe, H. Schwalbe et al. The mechanisms for organizing professional career management were analyzed by V. Biskup, D. Francis, G. Goldstein, L. Karamushka, V. Rybalka, M. Woodcock et al. Some methodical aspects of student career counselling were clarified by S. Alekseeva, V. Biskup, M. Klymenko, L. Kuzminska, D. Zakatnov et al. Only some papers disclose the technologies of professional career counselling and theoretically justify methods and models of student career counselling. However, the Internet promotes career coaching services, consulting services, tutoring practice, as well as scientifically unjustified, experimentally non-verified recommendations for organization and implementation of career counselling for the adult population.

Research methods include the following: theoretical analysis of the regulatory and legislative framework, researches on pedagogy, psychology, sociology and related sub-fields - to determine the coverage of the problem under study; theoretical analysis, comparison and generalization of conceptual views on the problem under study - to single out relevant aspects of the research; theoretical and methodical analysis, synthesis, logical generalization - to specify the functions of centres for professional career counselling; theoretical analysis, comparison, generalization - to identify achievements and failures in student career counseling; independent expert evaluation was partially used to evaluate the significance of the developed career counselling system; praximetric methods, including the study and analysis of long-term career counselling experience, programmes and concepts of career counselling centres - to clarify practices of student career counselling in vocational education institutions; oral and written surveys - to identify career orientations of future specialists and development levels of their career competency in the pedagogical context.

The article aims to analyze the conditions of student career counselling in vocational education institutions, identify its achievements and contradictory points and, therefore, justify some promising ways of their solving. This can be achieved only due to constructive cooperation between scholars and practitioners, namely, through the implementation of the system for career counselling in vocational education institutions developed by the Institute for Vocational Education of NAES of Ukraine.

Results and discussions. Professional career counselling is one of the effective psycho-pedagogical driving forces of career growth. The very concept was introduced only in the early 21 st century. Therefore, such terms as counselling in matters of career, counselling for career, career counselling, professional career counselling coexist in pedagogical discourse. The essence of career counselling is reflected in the communicative interaction between a counsellor (teacher, psychologist, tutor, mentor, coach) and an individual or a group of individuals when discussing some problematic situations, considering and determining the significance of the acquired competencies and experience.

The conducted analysis of the existing conditions proves that professional career counselling in vocational education institutions normally focuses on solving individual and personal internal conflicts in students, which may arise within professional selfdetermination and/or professional development. The most effective ways to do this are the following: 1) inventing alternative scenarios for successful selfrealization; 2) predicting prospects for career development with specified "achievable, measurable" goals, optimal ways and mechanisms for implementing each stage and type of activity; 3) imitating or "playing out" some work situations with focus on "authorship" of professional life; 4) discovering new meanings of professional activity in the context of preparing individual plans for professional development and career development; 5) motivating to transform the levels of needs, analyzing and adjusting ambivalent instructions, in particular when planning the paths of educational and professional career development; 6) promoting professional integrity of personality; 7) identifying probable risks, failures, crisis of professional development, etc.

The activities of centres for career counselling established as structural units at educational institutions are seen as an innovative way of implementing paradigmatic ideas of student career counselling. Within the functioning of such units, professional counsellors conditionally form "experimental groups of students" according to a specific criterion of essential characteristics of the problem under study, taking into account the corresponding volume of work. According to the criterion "interests and skills: the ratio and correlation", students from vocational education institutions were divided into four teams. The first team consisted of students, who lacked the necessary professional interests and skills to master the chosen profession. In this case, external positive motives (a right to scholarship; the advice of parents and friends, etc.) influenced the choice of the profession. When working with this group of students, it is important that counsellors motivate each individual towards selfanalysis in order to ignite interest in themselves, their skills and abilities and, finally, their own future. 
Personal development training (e.g., the knowledge cloud) can be rather effective at this stage. The second team consisted of students with the developed professional interests, who were eager to master the profession, but without clearly expressed inclinations for future professional activity. In this case, it is important that counsellors organize as many developmental programmes and training as possible. The third group consisted of students with advanced professional skills, but without clearly expressed interests in future professional activities, that is, they were unsure of what kind of activity they would like to do. In this case, it is vital to involve independent counsellors and career coaches in career counselling. The fourth group of students consisted of individuals with clearly expressed professional interests and developed skills for future professional activities. Therefore, when working with such students, it is important to conduct training sessions to improve existing professional inclinations and skills.

Thus, professional counsellors often have to be "experts" or "referees" to carry out various types of counselling and research activities. Nevertheless, their main task should be to develop models and specific mechanisms for preparing students for employment and successful self-realization and improving cooperation with employers.

As evidenced by the results of experimental institutions, student career counselling can be improved due to research activities focused on the process of forming career competency: experiments, sociometric studies, sociological surveys, tests, etc. They will have significant results if they are based on the collaboration between scholars from the Institute for Vocational Education of NAES of Ukraine, employees of centres for career counselling, teachers, heads of vocational education institutions and social partners. In order to provide high-quality scientific and methodological support to such centres, the scholars from the NAES of Ukraine offer to provide teachers from vocational education institutions with scientifically justified and practice-oriented materials prepared within the framework of implementing fundamental and applied research.

In the framework of fundamental research between 2016 and 2018, the employees of the Professional Career Laboratory developed, scientifically justified and experimentally verified a system of career counselling at the following stages: career guidance; forming career orientations during vocational training and employment.

Nonetheless, the problems related to the process of forming career orientations and further career development can be effectively solved if the system of counselling is viewed and implemented holistically.
According to D. Zakatnov (2011), the main aim of career guidance in vocational education institutions is not to prepare for professional self-determination, but for planning and realizing a professional career. Therefore, career counselling is a possible form of activities of educational institutions since it involves providing the student with certain career counselling services.

Aptitude, enthusiasm and moral responsibility are those important categories for forming professional and career orientations, which, unfortunately, are not incorporated in the State Standard for Vocational Training. Career orientations are interpreted as stable entities, which determine a professional path of an individual, are defined by value orientations and relevant philosophical priorities in choosing and modelling a professional trajectory. The function of career orientations is explained by an understanding of their essence as an internal source of career goals, which are characterized by a supertemporal personal and professional significance. Some typical psychological problems of forming career orientations, professional development of a modern person can be generally defined as follows: the inconsistency between the ideal and the real image of the chosen profession; the rejection of value orientations towards professional success in a market environment; the inconsistency between the real and ideal motivation towards professional self-actualization of personality under modern working conditions; non-relevant selfassessment of their own abilities and capabilities (lozowiecka, 2008). The authors of the article believe that the reason behind it lies in the inconsistency between the processes of professional and career orientation, which should complement each other based on the principle of continuity.

Social partners, relying on the ideas of foreign approaches to career planning, outline the relevant requirements for professional and personal qualities of employees at each stage of their career growth. Therefore, it is important to take into account modern requirements in the field of professional pedagogy and encourage teachers to form career orientation in students in vocational education institutions. These orientations, in turn, will contribute to optimal planning of career, rational clarity of goals, objective assessment of one's capabilities and acquired competencies and, finally, the discovery of effective ways to improve them and reconsider the values of professional and managerial experience.

The process of developing career orientations is a complex dynamic system of quantitative and qualitative changes, which somehow occur in the minds of students in vocational schools. After all, the applicants, who wish to be admitted to a vocational school, are necessarily informed about the advantages 
of a particular profession. In each lesson, teachers encourage future specialists to engage in cognitive activity and, therefore, pay attention to the predictability and viability of the acquired knowledge and skills, as well as their importance to professional success. Thus, they form the views on a possible professional future. However, it is essential that teachers master pedagogical technologies for forming and developing them or technologies of professional career counselling so that this process may become consistently stable and be transformed into a dynamic system for developing career orientations.

From a psycho-pedagogical point of view, an individual career based on self-knowledge, selfimprovement and self-organization is considered to be the most successful one. There are the main eight directions of career orientations, which E. Shein (1996) interprets as "career anchors". This is an important advancement, which ensures the observance of scientificity in career counselling. First of all, it refers to professional competency, that is, the orientation of people towards professional self-improvement. It is associated with the availability of abilities and capabilities for self-realization in a particular area of professional activity. People with such an orientation are eager to become real experts; they are especially happy when they are successful in the professional field, but they quickly lose interest in work that does not allow them to develop their abilities.

There are always students, who have certain leadership abilities and seek to lead other people. E. Shein (1996) defined this orientation as "management". In this case, the orientation towards integrating efforts of other individuals and readiness to be responsible for final results are of paramount importance. The process of developing this career orientation in future specialists is related to age and work experience. It can help to develop analytical skills and also contribute to interpersonal and group communication, as well as emotional balance. It must be noted, though, that individuals oriented towards leadership (management) believe that they have not achieved their career goals until they hold the post allowing them to lead the activities of other employees and thus contribute to production development.

Most future specialists are oriented towards autonomy (independence) and attempt to avoid organizational rules, regulations and restrictions. They tend to do everything in their own way, decide for themselves when and how much to work. Such students do not always want to obey the rules established in the institution. If such an orientation is clearly expressed, they do not pay much attention to the information about the system of vocational training and future career. They may also refuse to comply with the mentor's instructions and rules in order to preserve their independence. In the future, they may work in an area, which provides them with sufficient freedom and where they will not feel serious commitments or loyalty to the organization and will reject any attempts to limit their autonomy.

We should be able to notice students who appreciate stability. This career orientation (stability) is driven by the need for security and stability and the desire to make future life events predictable. It refers to a stable workplace or residence. With regard to a stable workplace, it is related to long-term work in a certain reliable organization with a good reputation, where they care about employees. The views of future specialists with such an orientation are characterized by readiness to shift responsibility for the development of their careers onto the employer. Another characteristic feature of orientation towards stability is unwillingness to change residence. In the future, stability-oriented specialists may show their ability to grow professionally. Preferring a stable job and life, however, they are able to refuse high posts if there may appear some risks or temporary inconveniences, even in the case of certain prospects.

The value orientations of people for whom career implies serving people are the following: working with people, serving mankind, helping people, readiness to make the world better. People with such a career orientation often choose a profession in the service sector, nature protection, quality control of products and goods, consumer rights protection, etc. They need recognition and respect for their serving humanity motivated by the desire to affirm their ideological beliefs. The process of developing such an orientation should be specified in the provision of services and the results of work set out by vocational training of future specialists.

People have to deal with many different life challenges. E. Shein (1996) views the concept of challenges and reaction to them as one of the types of career orientation. The main values of such a career orientation include the desire to win over others, overcome obstacles, solve difficult problems requiring the individual to mobilize his/her strengths and potentials, that is, competitiveness. Both struggle and victory are more important for him/her than a particular field of activity or qualification. Thus, a student from a vocational school or college with this orientation may consider arguments with groupmates and teachers as a game to be won. Novelty, diversity and challenges are rather valuable for them. They are not interested in simple things.

Career orientation defined as "an integration of lifestyles" is vital, too. When students are focused on the integration of various aspects and lifestyles, they 
do not believe in the prevalence of one particular sphere (education, family or career). They strive to balance various aspects and value their life in general, namely a place of residence, opportunities for selfdevelopment and self-realization, rather than an educational institution, a specific job or a post. When developing career orientations in students with such an orientation, it is important to notice positive moments in their behaviour and actions and, at the same time, motivate them to cooperate with other people and be open to changes taking into account their own interests and the interests of society.

Over the last few decades, the number of people oriented towards entrepreneurship has increased significantly. People with such a career orientation attempt to create something new, overcome obstacles and are ready to take risks. They do not want to work for others, are willing to create their own business, concepts or organizations and hope for financial success. In addition, they want their business to become a lifetime project, which will provide many opportunities for self-realization. People oriented towards entrepreneurship will continue their business even if they realize the probability of serious risks.

In Ukraine, the views of graduates from vocational schools on career are traditionally oriented towards the national industrial relations, in which financial incentives are the main stimulus of involving specialists in updating production and increasing productivity. A well-paid job is considered to be the most favourable workplace.

In the EU and the USA, scholars believe that people appreciate their own contribution to the cause rather than financial rewards. There is also an idea that a salary implies expectations and not a stimulus for creative self-realization (Zakatnov, 2011). The individual guided only by financial interests cannot regularly produce high-quality products since he/she is more oriented towards earnings than quality.

The motivation to make a career is one of the significant desires of students and expresses the level of willingness to realize their personal potential, as well as the views on professional success. Therefore, it is important that professional counsellors provide favourable conditions for students' self-awareness of their career priorities so that they may know what they can succeed in and how they can develop professionally. The diversity of orientations in social and professional interaction allows future specialists to enjoy their work, overcome problematic situations and strive for personal self-realization.

To this end, the research staff of the Professional Career Laboratory at the Institute for Vocational Education of NAES of Ukraine actively develop modern methods and technologies for forming career orientations, developing career and entrepreneurial competencies in future specialists. The conducted studies show encouraging results.

The employees of centres for career counselling established as structural units at educational institutions provide organizational, technical, informational and psycho-pedagogical support to professional and career development of individuals at the stage of acquiring vocational education, taking into account the peculiarities of vocational education institutions (students, training duration, profession-oriented training, prospects of employment and career development, etc.) and the needs of the labour market.

In vocational education institutions, the pedagogical effectiveness of professional career counselling for students is ensured through the implementation of the following professional organizational and methodical conditions in the practice of centres for professional career: providing psycho-pedagogical support of career development based on competency-based approach; activating and improving psychological services in vocational institutions; using interactive technologies of counselling, including computer technologies; creating a website for career counselling; enhancing motivation towards career growth, etc. Professional career counselling leads to positive changes in the hierarchy of factors, which influence the choice of a future career in terms of increasing the importance of pedagogical factors (career counselling, career guidance, etc.). However, the vast majority of respondents (over 90\%) indicate the need for career counselling.

The implementation of career counselling made it possible to successfully improve educational and professional trajectories of graduates from vocational education institutions, which resulted in a 9.3\% increase in the number of students planning to practice their professions. However, scientific and methodological support to centres for career counselling, provided by the employees of the Institute for Vocational Education of NAES of Ukraine, has increased the number of students who managed to prepare real long-term plans for career development (for more than 5 years). The implementation of career counselling in vocational education institutions has positively influenced the development of students' career competency by the indicators of such components as motivation and values, cognitive aspects, reflection and evaluation, activities and the mentioned integral entity in general.

Based on the study of the regulatory and legislative framework, analysis of theoretical studies on sociology, psychology, pedagogy and sub-fields of the mentioned sciences, Ukrainian and foreign experience, the main functions of centres for professional career counselling were specified: assessment and identification imply 
determining motives for choosing types and ways of professional career realization in students and graduates from vocational education institutions and identifying career orientations and development levels of career competency; educational communication is aimed at teaching students to use technologies of professional career planning by means of an individual and personal interaction, information exchange, identification, consolidation and recreation of relations and relationships, which form a system of values, norms, individual actions, ways of activity, consolidate and standardize the behaviour of students under the conditions of the labour market at the appropriate stages of civilizational progress; integration and coordination determine the cross-cutting activity vectors of the employees from centres for professional career counselling and the teaching staff from vocational education institutions as for vocational training of competitive workers, who are able to plan a professional career, strive for self-realization within the professional activity and professional growth based on the activation of such processes as grouping individuals with common interests and values orientations and cultivating a sense of mutual responsibility in the representatives of professional communities; sociological counselling and regulation include students' conscious comprehension of professional culture standards, social roles, normal (typical) patterns (stereotypes) of behaviour and mechanisms of their implementation, as well as the processes of forming value orientations and providing counselling services in the context of professional career planning; information provision and stimulation provide students with relevant information about probable ways of building a professional career and further career development, as well as the modern conditions of the labour market, in-demand professions, employers' requirements and also focus on timely identification of achievements and failures when building and realizing a professional career, applying methods aimed at consolidating, strengthening and developing positive changes and blocking or eliminating negative ones.

Provided that these functions are realized, centres for career counselling will become stable mechanisms for productive provision of the country's employment potential, which involves creating an information database on future specialists of a particular region, taking into account their psychological and physiological characteristics, skills, abilities, interests and aspirations, and will serve as a certain "knot-based constructor" for forming values and norms within society.

Conclusions. In Ukraine, the problems of professional orientation and employment are addressed by state employment centres and career counselling centres, which function as social projects or structural units at educational institutions. Based on the study on the activities of these centers, the following problematic aspects were outlined: the inconsistency in the information provided by job bank and the real demand in the labour market; a partial consideration of regional characteristics of the labour market; the inconsistency between the skills of graduates and employers' requirements; stereotypes, narrow and onesided views on the labour market, institutions, enterprises; low motivation of young people towards work, professional success and career growth; the imbalance between the realities of the regional labour market and the number of graduates with specific professions; an insufficient number of qualified counsellors, etc. In addition, career counselling focuses primarily on planning career, discovering rational ways of career development and modifying career development plans.

The mentioned problems can be solved if the content and functions of centres for career counselling in vocational education institutions are clarified.

\section{List of references}

Базиль, Л. та Орлов, В., 2018а. Консультування із професійної кар'єри як важливий чинник самореалізації майбутніх фахівців. В: Science and education a new dimension. Pedagogy and Psychology, VI (75), Issue 181, 2018, Nov, c. 7-11

Базиль, Л. та Орлов, В., 2018b. Методологія формування кар'єрних орієнтацій і досягнення професійного успіху. В: Конщептуальні засади розвитку освіти дорослих: світовий досвід, украӥнські реалії і перспективи: збірник наукових статей [колектив авторів]; за ред. Кременя В.Г., Ничкало Н.Г.; укл. Аніщенко О.В., Лук'янова Л.Б. Київ.: Знання України, 2018, с. 330-337.

Закатнов, Д. О., 2011. Професійна орієнтація як засіб соціалізації особистості. В: Формування світогляду особистості та соціальне конструювання сучасного світу: матеріали міжрегіональної наук.-практ. Конференції. Краснодон, Україна, 24 Червень 2011. Краснодон: Вид-во "Ноулідж", 2011, с. 49-53

Кови, С. и Колосимо, Дж., 2013. Правила вылающейся карьеры: пер. с англ. М. Мацковской. Москва: Манн, Иванов и Фербер; Эксмо, 2013.

Lozowiecka, W., 2008. Teoretyczne i praktyczne zasady ksztaltowania postaw konkurencyjnej zdolnosci jednostki. Edukacja i praca. Konteksty - wyzwania -antynomie. Bydgoszcz, 2008, s. 247-256.

Falkenberg, S., 1997. Factors in Employee Motivation. Satisfaction, [online] Available at: <http://people.eku.edu/ falkenbergs/motive.htm.> [Accessed 10 April 2019]. 
Shein, E. P., 1996. Three Cultures of Management: The Key to Organizational Learning. Sloan Management Review. Fall, 1996, p. 9-20.

\section{Translated \& Transliterated}

Bazyl, L. ta Orlov, V., 2018. Konsultuvannia iz profesiinoi kariery yak vazhlyvyi chynnyk samorealizatsii maibutnikh fakhivtsiv [Professional career counselling as an important factor of future specialists' self-realization]. V: Science and education a new dimension. Pedagogy and Psychology, VI (75), Issue 181, 2018, Nov, s. 7-11, [in Ukrainian].

Bazyl, L. ta Orlov, V., 2018. Metodolohiia formuvannia kariernykh oriientatsii i dosiahnennia profesiinoho uspikhu [Methodology for forming career orientations and achieving professional success]. V: Kontseptualni zasady rozvytku osvity doroslykh: svitovyi dosvid, ukrainski realii i perspektyvy: zbirnyk naukovykh statei [Conceptual principles of adult education development: the world experience, Ukranian realities and prospects: the collection of papers]/[kolektyv avtoriv]; za red. Kremenia V.H., Nychkalo N.H.; ukl. Anishchenko O.V., Lukianova L.B. Kyiv: Znannia Ukrainy, 2018 , s. 330-337, [in Ukrainian].

Zakatnov, D. O., 2011. Profesiina oriientatsiia yak zasib sotsializatsii osobystosti [Professional orientation as a means of personality socialization]. V: Formuvannia svitohliadu osobystosti ta sotsialne konstruiuvannia suchasnoho svitu [Forming an outlook of personality and social projection of the modern world: the proceedings of the interregional scientifical and practical conference]: mat-ly mizhrehionalnoi nauk.-prakt. konferentsii. Krasnodon, Ukraina, 24 Cherven 2011. Krasnodon: Vyd-vo "Noulidzh", 2011, s. 49-53, [in Ukrainian].

Kovi, S. i Kolosimo, Dzh.. 2013. Pravila vydayushcheysya karyery [How to build a successful career]: per. s angl. M. Matskovskoy. Moskva: Mann. Ivanov i Ferber; Eksmo. 2013, [in Ukrainian].

Lozowiecka, W., 2008. Teoretyczne i praktyczne zasady ksztaltowania postaw konkurencyjnej zdolnosci jednostki. Edukacja i praca. Konteksty - wyzwania -antynomie. Bydgoszcz, 2008, s. 247-256, [in Polish].

Falkenberg, S., 1997. Factors in Employee Motivation. Satisfaction, [online] Available at: <http://people.eku.edu/ falkenbergs/motive.htm.> [Accessed 10 April 2019], [in English].

Shein, E. P., 1996. Three Cultures of Management: The Key to Organizational Learning. Sloan Management Review. Fall, 1996, p. 9-20, [in English].

УДК 377.011.3-052:[331.36-027.56]:005.572

\section{Консультування 3 кар'єри: конструктивна взаємодія науки і практики}

\section{Людмила Базиль ${ }^{1}$, Валерій Орлов²,}

1 доктор педагогічних наук, доцент, учений секретар Інституту професійно-технічної освіти НАПН України

2 доктор педагогічних наук, професор, головний науковий співробітник лабораторії професійної кар'єри Інституту професійно-технічної освіти НАПН України

Реферат. У статті проаналізовано дійсний стан консультування учнівської молоді закладів професійної (професійно-технічної) освіти (далі:ЗП(ПТ)О), виявлено напрацювання з означеної проблеми та суперечливі моменти консультування. Обгрунтовано, що у ЗП(ПТ)О консультування з професійної кар'єри традиційно зводиться до перегляду й розв'язання внутрішніх конфліктів учнів у межах професійного самовизначення. Значним досягненням у реалізації ідей кар'єрного консультування учнівської молоді позиціоновано діяльність центрів кар'єри. Водночас на основі теоретичного аналізу, порівняння, педагогічних спостережень і логічного узагальнення уточнено типові проблемні аспекти кар'єрного консультування в межах професійного становлення сучасної особистості, що цілісно зводяться до невідповідностей ідеального й реального образів обраного фаху, суб'єктивного сприйняття й ігнорування ціннісних орієнтацій щодо професійного успіху та кар'єрного зростання в умовах ринкового середовища, неадекватності самооцінки індивідуально-особистісних якостей тощо. Авторами запропоновано перспективні способи вирішення проблемних аспектів консультування учнів закладів професійної (професійнотехнічної) освіти, що концептуалізуються в механізмах продуктивної інноваційної взаємодії науковців Інституту професійно-технічної освіти НАПН України з педагогічними працівниками й реалізуються в рамках упровадження системи консультування з професійної кар'єри в закладах професійної (професійно-технічної) освіти.

Ключові слова: професійна кар'єра, иентри професійної кар'єри, консультування учнівської молоді, консультування з професійної кар'єри, професійно-технічна освіта. 